DOI: https://doi.org/10.32839/2304-5809/2021-5-93-66

УДК 343.6

Харламова Д.В., Іноземцев М.Д.

Національний юридичний університет імені Ярослава Мудрого

\title{
БОРОТЬБА ПРОТИ ДОМАШНЬОГО НАСИЛЬСТВА В УКРАЇНІ ТА СВІТОВА ПРАКТИКА
}

\begin{abstract}
Анотація. У статті розглянуто проблеми виникнення домашнього насильства, причини дискримінащійного становища жінок у суспільстві, проаналізовано досвід зарубіжних країн та міжнародні інструменти i національні практики протидії домашньому насильству і запропоновано інструменти допомоги в боротьбі та профілактиці насильства щодо жінок. Важливою частиною дослідження є огляд причин та умов відмови України від ратифікації Стамбульської конвенції та визначення засад необхідності ратифікації даного міжнародного акта, створеного під егідою Ради Свропи і відкритого для будь-якої країни світу. Як висновок, у статті пропонуються нові ефективні методи та шляхи протидії домашньому насильству.
\end{abstract}

Ключові слова: домашнє насильство, гендерна нерівність, протидія домашньому насильству, ратифрікація Стамбульської конвенції.

Kharlamova Daria, Inozemtsev Mykola Yaroslav Mudryi National Law University

\section{COMBATING DOMESTIC VIOLENCE IN UKRAINE AND WORLD PRACTICE}

Summary. This article is devoted to the phenomenon of domestic violence, which was investigated through the prism of criminal law by the author. The article pays enough attention to the analysis of the historical preconditions for the emergence of domestic violence and women discrimination in Ukraine. To prove the existence of the problem of violence, the authors analyze the measures of sentencing under the laws of different historical epochs in Ukraine. The article considered analyzed the experience of foreign countries and international instruments and national practices to combat domestic violence and proposed tools to help combat and prevent violence against women. The beginning of this article is necessary, though inconvenient step in order to give strength to the movement "to end gender-based violence.» The domestic violence movement historically framed its work on a gender binary of men as potential perpetrators and women as potential victims. An important part of the research review discussed the causes and conditions Ukraine refusal to ratify the Istanbul Convention. This article also defines the principles of the need to ratify this international act, created under the auspices of the Council of Europe accessible to any country in the world. Thus, in conclusion, the article proposes new effective methods and ways to combat domestic violence. This article analyzes not only the national criminal law, but the criminal law of foreign countries, such as the United States, China, France and Germany. In the same article, it was found models of public and private response to domestic violence. This article makes a feminist case for recognizing male violence as inappropriate. Domestic violence is one of the leading problems that the feminist movement is trying to solve. The article concludes that in the broadest sense of the use to women: strength, power, coercion, control and violence - it is illegal and cannot be reconciled with any good intentions. From our law practice today we see the following: you have to really suffer in order to be protected by the state. «From this follows the following thought: «It is necessary to change the attitude to the problem, and not only the laws».

Keywords: domestic violence, gender inequality, resistance of violence, ratification of the Istanbul Convention.

$\Pi$ остановка проблеми. Проблема домашнього насильства, корінням якого є гендерна нерівність, є доволі гострою глобальною проблемою, яка, хоча і має відмінності у локальних контекстах, тим не менш будується на укорінених соціальних стереотипах, які $є$ розповсюдженими у всьому світі та побудовані на нерівностях у становищі жінок та чоловіків, що склалися історично.

Статистика стверджує: принаймні одна 3 трьох жінок у всьому світі була побита, примушена до сексу або іншого насильства протягом свого життя. За даними Ради Свропи від 20\% до 50\% жінок є жертвами насильства в сім’і [1].

3 початком пандемії COVID-19 проблема набула ще більш масштабного вираження. Протягом першої половини 2020 року до української поліції надійшла 101 тисяча викликів через домашне насильство. Це на 40\% більше порівняно 3 тим же періодом 2019 р. [2].

Дана проблема актуальна не тільки для України, а й для усього світу. Під час пандемії коронавірусу багато країн повідомляють про загострен- ня проблеми насильства в сім'ї та в партнерських стосунках. Генеральний секретар Організації Об'єднаних Націй Антоніу Гутерріш, відзначаючи «жахливий глобальний сплеск насильства», закликав до «припинення вогню» у домогосподарствах. Свропейський Парламент заявив: «ми не залишимо жінок Свропи сам-на-сам із проблемою». Згадані міжнародні інституції закликали посилити підтримку жертв насильства в сім'ї під час пандемії. Традиційно таке насильство розглядається як гендерно-зумовлене, і з цієї точки зору частіше його жертвами є жінки [3].

Аналіз останніх досліджень та публікацій. Окремі аспекти кримінальної відповідальності за домашне насильство досліджували у своїх працях Н. Аніщук, А. Байда, А. Бова, О. Дудоров, О. Кісь, М. Хавронюк, О. Харитонова, К. Шуневич та інші. Разом 3 тим, оскільки з початком пандемії COVID-19 проблема домашнього насильства стала ще більш поширеною, важливим кроком для їі вирішення є аналіз теоретичних та практичних питань, що виникають 
у зв'язку з ратифікацією Україною Стамбульської конвенщії та можливостями застосування передбачених нею засобів та механізмів протидії домашньому насильству.

Виділення невирішених раніше частин загальної проблеми. Дослідження важливості проведення просвітницької та профрілактичної роботи 3 попередження гендерного насильства та домашнього насильства 3 урахуванням досвіду та кращих практик зарубжіних країн та аналіз особливостей розвитку домашнього насильства під час пандемії.

Мета статті: проаналізувати кримінальне законодавство різних країн та з'ясувати моделі державного та недержавного реагування на домашне насильство, обгрунтувати важливість ратифікації Стамбульської Конвенції Україною та запропонувати нові ефективні шляхи протидії домашньому насильству.

Виклад основного матеріалу. Все має своє коріння, людський мозок не "алогічна коробка", яка керується лише почуттями. Людям притаманно знаходити у всьому певні закономірності, які не виникають просто так: дія кожної людини має свою причину та наслідок.

Тож, у чому полягають причини домашнього насильства і як взагалі воно виникло? Що зумовило дискримінаційне становище жінок у суспільстві та в сім'ї?

В давні часи, коли фізична сила була умовою виживання, чоловіки, головним ресурсом яких була фізична сила, отримували владну перевагу. До того ж, в давнину насильство на сімейно-побутовому грунті протягом тривалого часу в багатьох країнах розглядали як форму належної поведінки, як елемент «виховання». Аналіз нормативноправових актів різних епох і держав свідчить, що насильство у сім'ї залежить від стереотипних уявлень про гендерні ролі, які склались у тому чи іншому суспільстві, а також від того, як релігійні норми впливають на ставлення до насильства і формування суспільних цінностей.

Аналізуючи законодавство Київської Русі, слід зазначити, що воно закріплювало нерівність людей за ознаками статі та соціального стану. Можна констатувати, що існували норми, які обмежували права жінок у порівнянні 3 чоловіками. Так, згідно з Просторовою редакцією Руської Правди за вбивство жінки покарання суттево відрізнялось, ніж за вбивство чоловіка. Хоча винного за вбивство жінки судили тим же судом, що і за вбивство чоловіка: стягувалась грошова пеня на користь князя (віра) та винагородження на користь родичів вбитої (головщина), проте умови віри були різними. Життя жінки захищалося лише половинною вірою в 20 гривень. Для порівняння: за вбивство чоловіка була встановлена подвійна віра в 80 гривень у разі вбивства княжого чоловіка або члена старшої князівської дружини, або проста віра в 40 гривень за вбивство простого вільного чоловіка. Отже, віра за вбивство жінки була вдвоє і навіть вчетверо разів меншою, ніж за вбивство чоловіка. По суті, вбивство жінки прирівнювалось до таких злочинів, як тяжкі каліцтва, відсічення руки, ноги, носа, ушкодження ока [4, с. 155-158].

Значну роль у ставленні до проблеми домашнього насильства відіграє релігія. В багатьох країнах релігійні норми стверджують перевагу чоловіків над жінками. В християнському Новому Завіті містяться такі твердження: «Чоловік ... образ і слава Богу, а жінка - чоловікові слава. Бо чоловік не походить від жінки, але жінка від чоловіка». Твердження, що з ребра Адама Бог створив жінку, тлумачиться як те, що вона фрактично Адаму належить. Вшиті в суспільну свідомість, такі погляди призводять до стигматизації жінок і увічнення влади чоловіків через релігійні коди, культурні коди.

Нерідко можна почути думку, що в українській традиційній культурі панував матріархат. Але, як стверджуе у своїх працях Оксана Кісь - відома науковиця, антропологиня, феміністка, - насправді гумористичні пісні й загалом фольклор сатиричного характеру, в яких сильна жінка верховодить у родині, звертають увагу на явища, котрі були, радше, винятком. Етнографічні матеріали засвідчують, що вкрай рідко траплялося, щоб жінка в родині домінувала, і чоловіка такої жінки, як правило, в громаді не поважали. Загалом вважалося, що жінка не має права навіть голос на чоловіка підвищити, а не те що застосовувати до нього фрізичну силу. «Не могло такого бути, щоб жінка била чоловіка, тоді як зворотні практики насильства над жінками у родинах були дуже поширеним явищем», - підкреслюе Оксана Кісь. Чоловік мав право «виховувати» свою дружину, карати їі, якщо вона поводилася «негідно». Це відображено у фольклорі - наприклад, приказках на кшталт: «Жінка не бита - як коса не клепана». Отже, сімейне насильство не тільки толерувалось, а й легітимізувалось - за чоловіком визнавали право застосування фрізичної сили до дружини, щоб «наставити їі на путь істинний» [5, с. 217].

3 часу проголошення незалежності України та падіння «залізної завіси» у свідомості українського жіноцтва відбулися значні зміни. Ідеологічно насаджуваний канон фремінності - «працююча мати» - втратив свою монополію. У 1990-х роках йому на зміну прийшли нові життєві стандарти, моделі поведінки, цінності та моральні норми. На той час існувало принаймні два основні джерела для вибудовування нової системи цінностей: по-перше, ідеологія українського націоналізму, співвідносна з історичним минулим і традиційною культурою українців; по-друге, досі незнані і вкрай привабливі «західні взірці» сучасної цивілізації.

В сучасній Україні продовжують домінувати ті моделі фемінності, що репродукують гендерні стереотипи та оріентують жінку на самореалізацію через зв'язок із чоловіком, у межах традиційних ролей матері, домогосподарки, дружини [6].

Разом 3 тим ми можемо спостерігати певні зміни у суспільствах, законодавствах та практиках протидії домашньому насильству.

Так, в Іспанії основними методами реагування на домашне насильство є здійснення систематичного контролю за сімейними правопорушниками та практика обов'язкового реагування на всі насильницькі дії щодо неповнолітнього, відповідно до якої в разі вчинення правопорушення застосовується обов'язковий арешт, обов'язкове судове провадження, обов'язкове інформування громадськості про такий фракт. Цікаво, що 
Іспанія першою запустила пілотні програми електронного спостереження, спрямовані на агресорів і жертв домашнього насильства [7, с. 168].

У Кримінальному кодексі ФРН окремо акцентуеться увага на питанні відповідальності за dрізичне насильство щодо неповнолітніх ст. 225 «Катування опікуваних осіб», відповідно до якої муки, катування, заподіяння шкоди, а також зловмисне нехтування своїм боргом піклуватися про особу, якщо таке насильство застосовуеться до особи, що не досягла вісімнадцятирічного віку або особи, яка беззахисна внаслідок хвороби або фрізичного недоліку, яка знаходиться під опікою або заступництвом, відноситься до сімейства, надана в розпорядження особи, зобов'язаної здійснювати їй матеріальну соціальну допомогу, або підлегла ій у рамках службових і робочих стосунків, караються позбавленням волі на строк від шести місяців до десяти років [8].

США має великий досвід попередження насильства в сім’ї. Згідно з даними Національної коаліції США проти домашнього насильства, $25 \%$ жінок зазнають домашнього насильства протягом життя.[9] Крім інституту охоронних ордерів, для протидії домашньому насильству у США використовують й інші механізми, а саме інститут спеціалізованих судів, які розглядають справи про насильство в сім'ї. Всього у США фрункціонуе понад 200 таких судів. Для запобігання насильству в США реалізована стратегія обов'язкового реагування. Медичні заклади зобов'язані повідомляти про будь-які фракти насильства [9, с. 151].

Більш ніж в 30 штатах США прийняті нормативно-правові акти, що забороняють або обмежують проживання осіб, які засуджені за сексуальні злочини, поблизу місщь, що відвідують діти. Окрім того, закріплена конкретна відстань, на яку підконтрольним особам заборонено наближатися до охоронюваного об'єкту. Покарання за вчинення домашнього насильства в США диференціюеться в межах від декількох місяців до 3-5 років позбавлення волі. При цьому ступень суворості покарання залежить від: 1) ознак суб'єкта злочину (громадянин США або іноземещь, особа без громадянства, біпатрид); 2) розміру заподіяної шкоди; 3) штату, в якому стався інцидент [10, с. 211].

У ст. 260 КК Китайської Народної Республіки передбачаеться, що жорстоке поводження 3 членами сім'ї при обтяжуючих обставинах карається позбавленням волі на строк до 2 років, арештом або наглядом. Ці ж дії, якщо вони спричинили тяжкі каліцтва або смерть потерпілого, караються позбавленням волі на строк від 2 до 7 років.

Насильство в сім'ї є найбільш поширеним у світі, але досі маловизнаним порушенням прав людини, і насамперед прав жінок, будучи крайньою формою соціостатевої нерівності. Дослідження засвідчують, що у тих суспільствах, де фрігурує Іендерний паритет у відношеннях, особливо у сімейному середовищі, $є$ практично відсутнім таке явище, як гендерне насильство [11, с. 16].

На жаль, нині у більшості країн світу не досягнуто реальної рівноправності статей у всіх сдерах життедіяльності суспільства, що вказує на гостроту проблеми гендерного насильства. Вочевидь, процеси зміни стереотипів щодо привілейованого становища чоловіків стосовно жінок в суспільстві $\epsilon$ довготривалими і потребують серйозних зусиль як державних, так і недержавних акторів.

Україна, яка знаходиться на шляху до євроінтегращї, також не стоїть осторонь проблеми домашнього насильства, створивши власну модель реагування на дане явище. Окрім появи ст. 126-1 «Домашне насильство» у Кримінальному кодекci, у статті 67 КК передбачена обтяжуюча обставина "вчинення кримінального правопорушення щодо подружжя чи колишнього подружжя або іншої особи, 3 якою винний перебуває (перебував) у сімейних або близьких відносинах» (п. 6-1 ч. 1 ст. 67 КК) та розширено зміст п. 6 ч. 1 ст. 67 КК за рахунок "вчинення кримінального правопорушення ... у присутності дитини». В деяких складах кримінальних правопорушень передбачено кваліфікуючу обставину: «вчинення кримінального правопорушення щодо подружжя чи колишнього подружжя або іншої особи, з якою винний перебуває (перебував) у сімейних або близьких відносинах». Не варто забувати й про статтю 91-1 щодо обмежувальних заходів, що застосовуються до осіб, які вчинили домашне насильство.

Отже, як бачимо, законодавець намагається слідувати світовим тенденціям і створити важелі для ефрективної протидії домашньому насиллю, хоча правозастосовну практику очікуе непростий шлях подолання гендерної нерівності [12, с. 43-45, 51-52]. Очевидно, що вирішення питання домашнього насильства можливе лише за умови об'єднаних зусиль боротьби 3 ним, з'ясування прерогатив у вживанні спеціалізованих контекстів перед загальними підходами. Уявлення про те, що боротьба з домашнім насильством вимагає забезпечення як термінового захисту, так i довгострокового, артикулюе необхідність пошуку оптимальних правових рамок для зниження рівня розповсюдженості насильства. Пропорщійність кримінально-правової «відповіді» на домашне насильство потребуе встановлення адекватного співвідношення між ціллю, яка має бути досягнута, та засобами їі досягнення. Суттевий прогрес у напрямку протидії домашньому насильству в Україні відбувся саме у зв'язку 3 прийняттям ЗУ від 06.12.2017 р. № 2227-VIII «Про внесення змін до деяких законів України у зв'язку з ратифрікацією Конвенції Ради Свропи про запобігання насильству стосовно жінок і домашньому насильству та боротьбу з цими явищами», ЗУ від 07.12.2017 р. № 2229-VIII «Про запобігання та протидію домашньому насильству».

Конвенція Ради Європи про запобігання насильству стосовно жінок і домашньому насильству та боротьбу із цими явищами (Стамбульська конвенція) є одним 3 найбільш визначних міжнародних актів щодо протидії домашньому насильству. Відповідно до статті 3 цієї Конвенції «домашне насильство» означає всі акти фрізичного, сексуального, психологічного або економічного насильства, які відбуваються в лоні сім'ї чи в межах місця проживання або між колишніми чи теперішніми подружжями або партнерами, незалежно від того, чи проживає правопорушник у тому самому місці, що й жертва, чи ні або незалежно від того, чи проживав правопорушник у тому самому місці, що й жертва, чи ні. Проаналізувавши преамбулу, бачимо, що держави-учасниці Ради Свропи визнають, що жінки й дівча- 
та піддаються більшому ризикові насильства за гендерною ознакою, ніж чоловіки; домашне насильство зачіпае жінок непропорційно, хоча і чоловіки також можуть бути жертвами домашнього насильства; діти є жертвами домашнього насильства, у тому числі як свідки насильства в сім'ї. Саме тому країни, які підписали Конвенцію, прагнуть створити Свропу, вільну від насильства стосовно жінок і домашнього насильства.

Значущість і унікальність Конвенції полягає у тому, що вона визнає насильство щодо жінок водночас і порушенням прав людини, і видом дискримінації. Стамбульська конвенція не просто адаптувала підхід «3-Р» - Prevention, Protection, Prosecution - встановивши, що сторони Конвенції зобов'язуються попереджати гендерне насильство, захищати від гендерного насильства, переслідувати за гендерне насильство. Ï̈̈ успіхом і безперечним плюсом стало те, що, приймаючи необхідність більш продуктивного реагування, розробники включили ще одну «Р» до рамки Стамбульської конвенції, зобов'язавши країни здійснювати інтеграцію політик (Policy integration). Це означає, що подолання насильства стосовно жінок можливе не тільки завдяки кримінально-правовим та кримінально-процесуальним механізмам, а і завдяки інтегрованим політикам, спрямованим на впровадження субстантивної рівності між жінками та чоловіками [13, с. 344]. Існує зв'язок між досягненням гендерної рівності і зниженням рівня насильства.

Головна новизна Конвенції полягала у тому, щоб врахувати історичні нерівності, вплив існуючих патріархальних структур на соціальний статус жінок та чоловіків та їхні сощіальні можливості. Адже гендерні нерівності укорінені структурно - на мікро-, мезо- і макрорівні. ЖЖінки обмежені у доступі до ресурсів - політичних, екномічних, часових, інформаційних, а отже більш уразливі до насильства. Так, наприклад, жінки недостатньо представлені в політичному процеci. Незважаючи на те, що вони складають приблизно половину населення земної кулі, тільки 18,4\% представниць національних парламентів i 17 глав держав і урядів у всьому світі становлять жінки. Жінки становлять лише 3\% президентів найбільших компаній Свропи.

Наві Піллей, Верховний комісар $\mathrm{OOH} \mathrm{з} \mathrm{прав}$ людини у своїй промові зазначив, що тільки тоді, коли жінки повною мірою візьмуть участь у процесі прийняття рішень та організаційному будівництві, їх перспектива буде по-справжньому інтегрованою. Поняття демократії по-справжньому буде чітко зрозумілим тільки коли прийняття політичних рішень буде розподілено однаково між чоловіками і жінками і буде гарантована повна участь жінок в інституційній розбудові.

Станом на сьогодні Стамбульська конвенція підписана, але не ратифрікована Україною, хоча спроби ратифікувати Стамбульську конвенцію робилися. Це питання було винесено на розгляд Верховної Ради України 14 листопада 2016 року. Але більшість депутатів наголошували на тому, що даний документ містить «норми, які не прийнятні для українського суспільства і української духовності».

Наприклад, цитата з виступу депутата М. Папієва: «Для того щоб ви розуміли, що ми зараз узаконюємо, я вам наведу тільки одну цитату 3 статті 3 ціеї Конвенції, яка говорить про те, що гендер означає соціально закріплені ролі, поведінку, діяльність і характерні ознаки, яке певне суспільство вважає належними для жінок та чоловіків. Тобто після ратифрікації ціеї Конвенції головними є... вже будуть не фрізіологічні ознаки чоловіка чи жінки, а вже головними стануть соціальні ознаки: чи ідентифрікуе ця людина себе як чоловіка, чи ідентифікуе вона як жінка. I апріорі, якщо перед вами стоїть фрізіологічний чоловік, ви не можете до нього звернутися, поки він не ідентифікуе себе по гендеру, до кого він належить. Тобто, шановні, це достатньо така дискусійна позиція, i я думаю, що нам передчасно, не провівши широке обговорення у тому числі і в громадських організаціях, в релігійних конфесіях, нам передбачено зараз отак поспіхом провести ратифікацію цієї Конвенщії» [14].

Проти ратифрікації також виступає Рада церков, апелюючи до згадки «гендеру» у Конвенції. Ймовірно, ці побоювання пов'язані з низьким рівнем обізнаності у сфрері гендерної теорії, адже гендер - це соціальне існування статі, ті очікування, які суспільство пред'являе особам тієї чи іншої статі; розуміння того, як гендерні ролі покладаються на людину в процесі соціалізації і як конструюютиься соціальні стереотипи, дає можливість зробити соціальне середовище більш зручним і комфортним для кожної людини.

Слід розуміти, що даний міжнародний договір створений для захисту від насильства та дискримінації. Рівноправність між жінками та чоловіками як за законом, так і на практиці, займає центральне місце в припиненні насильства стосовно жінок, про що і йдеться в тексті конвенції.

Стамбульська конвенція є частиною розгалуженої системи міжнародних механізмів захисту прав людини. Стамбульська конвенщія є спеціальною відносно Свропейської конвенщї з прав людини у питанні захисту прав жінок, представляе найвищий рівень захисту, проте це не означає, що механізми ЄКПЛ не можуть бути задіяні. Вони також працюють і залишаються едективними.

Так, заслуговуе на увагу рішення ЄСПЛ "Levchuk v. Ukraine" (Application no. 17496/19), яке стало першим рішенням ССПЛ щодо домашнього насильства в Україні [15].

Заявниця у справі стверджувала про порушення статей 6,8 та 13 Свроконвенції у зв'язку 3 відмовою в задоволенні позову про виселення, поданого нею проти колишнього чоловіка, оскільки він неодноразово піддавав їі психологічному та фізичному насильству в присутності їхніх неповнолітніх дітей.

Ірина Левчук - мати чотирьох дітей, має інвалідність третьої групи. Вона чимало разів зверталася в поліщію зі скаргами на домашне насильство з боку иї чоловіка, але провадження або не відкривали, або обмежувалися усними попередженнями. Якщо матеріали розслідування передавали до суду, то розгляд справи закінчувався угодою про примирення. Вона піддавалась насильству навіть після розлучення 3 чоловіком у 2015 році.

22 червня 2016 року жінка подала цивільний позов про виселення чоловіка 3 квартири (за стаття 116 Житлового кодексу), оскільки вирішила, що це буде єдиний ефективний спосіб 
захистити себе і дітей. Судове провадження в національній правовій системі тривало понад два роки на трьох рівнях юрисдикції. Міський суд задовольнив позов заявниці; апеляційний суд зазначив, що за даних обставин немає підстав застосування такого крайнього заходу, як виселення, хоча зауважив на необхідність попередити кривдника про те, що йому необхідно змінити своє ставлення до правил сумісного проживання з членами сім'ї після розлучення; Верховний Суд підтримав висновки апеляційної інстанції.

Розглядаючи дану справу, ЄСПЛ зауважив, що, відхиляючи позов жінки про виселення колишнього чоловіка, національні суди продемонстрували нездатність провести всебічний аналіз ситуащії та оцінити ризик майбутнього психологічного та фрізичного насильства щодо заявниці та дітей, ба більше - тривалість судового провадження наражала їх на ризик подальшого насильства.

ЄСПЛ констатував, що така відповідь судів на позов заявниці про виселення їі колишнього чоловіка не відповідає позитивному зобов'язанню держави забезпечити ефрективний захист заявниці від домашнього насильства [16].

Правове значення даного рішення ССПЛ полягає у тому, що це рішення вкотре нагадало про захист прав людини та основоположних свобод й те, що суди мають надавати пріоритет правам жінок на життя та фрізичну і психічну цілісність порівняно з правами кривдників й викорінювати причини гендерного насильства.

Конвенція закликає залучати до роботи у боротьбі 3 насильством щодо жінок та домашнім насильством усі відповідні державні установи та служби для координації діяльності. Це означає, що державні установи та неурядові організащії в ідеалі повинні діяти на основі угод про співпрацю [17].

Так, основними інструментами допомоги в боротьбі та профілактиці насильства по відношенню до жінок є жіночі притулки, кризові центри, телефронні лінії допомоги та інформаційні кампанії. Жінки об'єднуються в організації, а ті, в свою чергу, - у мережі. Однією з таких мереж є WAVE (Women Against Violence in Europe) - мережа європейських жіночих неурядових організацій та експертів у сорері запобігання насильству над жінками та їх дітьми.

17 із 46 країн Свропи мають безкоштовні телефонні лінії допомоги, які працюють 24/7. Тільки 37\% европейських країн відповідають стандартам, встановленим у Стамбульській конвенщії. Тільки 10 з 28 країн-членів ЄС мають безкоштовні телефонні лінії допомоги, що працюють цілодобово.

В Україні вже діє цілодобова Нащіональна «гаряча лінія» 3 попередження домашнього насильства, торгівлі людьми та гендерної дискримінації 0800500335 або 386 (короткий номер 3 мобільного), на базі Міжнародного правозахисного центру «Ла Страда Україна».

У країнах, які не мають спеціалізованих ліній допомоги постраждалим від насильства жінкам, основну допомогу забезпечують інші лінії допомоги (лінії допомоги дітям та лінії щодо боротьби з домашнім насильством, лінії для етнічних меншин та іммігрантів).

В Свропі існує 1842 притулки для жінок-жертв домашнього насильства. Вони забезпечують приблизно 26785 місць для жінок і дітей [18].
Окрім притулків існують також жіночі консультаційні та кризові центри. Всі 46 країн Свропи надають послуги підтримки жертвам насильства - жіночі кризові або консультаційні центри, центри для жертв згвалтування, проактивні центри, регіональні центри домашнього насильства. Всього в Європі діє 2937 спеціальних центрів. Розподіл їх нерівномірний - $86 \%$ розташовано в «старих» країнах-членах ЄC і лише 6\% - у «нових» країнах [17].

Висновки та пропозиції: Якими ж можуть бути ефективні шляхи протидії домашньому насильству?

\section{1. Не ловчати та не бути байдужили!}

Під час святкування Дня жінок в Південній Афрриці у 1996 р. президент Нельсон Мандела виголосив таку промову: «Якщо хороша людина нічого не робить, коли погана людина чинить насильство над жінками - ця людина нічим не краща за кривдника. Немає нічого гіршого для жіночої гідності, ніж насильство. I кривдник, і мовчазний спостерігач обидва створюють небезпечне суспільство».

I це дійсно так. Більшість жертв сприймає насильство як нормальне та невідворотне явище, і тому замовчують фракт сам фракт його вчинення, але мовчанка веде до повторення циклу насильства. Свідки також часто замовчують побачене i не намагаються допомогти тим, хто став жертвою насильства, оскільки або їх про це попросили самі постраждалі, або вони вважають, що це приватна справа сім’і, або бояться погроз з боку кривдника. Але домашне насильство може спинити лише небайдужість. Тому сьогодні для того, щоб зусилля у боротьбі з домашнім насильством не виявилися марними, треба не залишатися байдужими до його проявів, формувати нульову толерантність до домашнього насильства.

\section{2. Знати свої права та алгоритли дій.}

Важливим $є$ інфрормування людей про їх право на вільне від насильства життя, про невідворотність покарання за будь-яке насильство з моменту повідомлення про нього, про неприпустимість самоствердження через насильство над слабшими, над жінкою лише через те, що вона жінка, про замовчування насильства. Не існуе ніяких конфіденційних заборон за фрактами домашнього насильства! Кожна людина має право знати алгоритм дій загрозливій ситуації. Тож вбачається за потрібне ввести обов'язкові короткі сощіальні реклами та повідомлення про порядок дій при вчиненні домашнього насильства на національному телебаченні, у соціальних мережах та ЗМI.

3. Проводити інфборлачійно-просвітницьку, проббілактичну та методичну роботу з лолоддю

Одним із важливих заходів профрілактики насильства є формування у школярів та студентів освітніх закладів умінь і навичок розвитку і підтримки здорових міжособистісних відносин. Для цього варто внести до освітнього плану закладу освіти програми, які навчають дітей навичкам керування своєю поведінкою, дієвим способам вирішення конфрліктів. Необхідним є і обговорення питань, пов'язаних з сексуальним і репродуктивним здоров'ям і поведінкою, адже діти та підлітки часто стають жертвами саме сексуального насильства. 
Так, з вересня 2020 року в Англії та Уельсі діють нові обов'язкові правила, що включає навчання "всім молодим людям, як зберігати безпеку», шляхом сприяння здоровим стосункам. Профрілактична освіта про те, як розпізнавати жорстокі та нездорові стосунки, швидше за все, буде більш економічно вигідною, ніж послуги, що стосуються наслідків жертв або реабілітаціі винних. Навчання дітей здоровим стосункам до десяти років є життево важливим, оскільки після цього моменти ставлення та поведінка стають кристалізованими та стійкими до змін [19].

Дитина має розуміти такі поняття, як гідність, рівність, виховуватися у дусі гендерної рівності та формуватися як цілісна особистість, не зазнаючи психологічних травм. Важливо, аби дитина відчувала підтримку вчителів та психологів, отже значну увагу необхідно приділити побудові взаємовідносин з учнями. Якщо вчитель виявить факт вчинення домашнього насильства у дітей чи отримае про це заяву чи повідомлення, він зобов'язаний повідомити про це службу у справах дітей та Нацполіцію не пізніше ніж за добу, організувати роботу практичного психолога та соціального педагога з постраждалими дітьми.

Для сучасного покоління найкращим способом $е$ прочитання книг та перегляд відео-матеріалів, фільмів. Часом історії на екрані допомагають зрозуміти певне явище краще, ніж десяток лекцій чи статей. Таким $е$, наприклад, фрільм «Скарб», де завдяки небайдужості та зусиллям вчительки і соціальних працівників була врятована від насильства дівчина-підліток.

Безпечне суспільство - це коли дитину навчають, що насильство - це погано. I якщо тебе вдарили вдома, скривдили в інший спосіб чи ти став свідком такої ситуації - маєш про це обов'язково повідомити (102, гаряча лінія). Ми звикли чути банальну фрразу про те, що домашне насильство - це сміття, яке прийнято залишати вдома. Але і суспільство, і поліція мають усвідомлювати, що про це не варто мовчати, і насильство не мае приховуватися за ілюзорним затишком домашніх стін.

4. Збільшувати зусилля місцевої влади.

Органи місцевого самоврядування мають організовувати соціальні послуги, брати участь у підготовці фахівців, які будуть боротися з домашнім насильством і визначати, які спецслужби з підтримки постраждалих потрібні регіону, забезпечувати їхне створення i функціонування. Медики повинні повідомляти місцевій владі та Нацполіції про ушкодження, які пацієнт міг отримати через домашне насильство, бо в даному випадку конфіденційність та лікарська таємниця, на нашу думку, має другорядне значення порівняно із захистом життя та здоров'я людини. Інтеграція політик, яку пропонуе Стамбульська конвенція, означае, що у боротьбі з насильством щодо жінок та домашнім насильством важливе значенння мае координація зусиль на різних рівнях - як на державному, так і на місцевому.

Мета нашої роботи полягала не лише у тому, щоб показати покарання за насильство у різних країнах, а і донести меседж: така проблема може стосуватися кожного, незалежно від соціального становища, географічних, релігійних чи інших кордонів. Саме тому лозунг нашої дослідницької групи звучить так: «In unum adversus violentiam!» - «Разом проти насильства!».

$\mathrm{У}$ цього правопорушення не може бути ніяких виправдань, про нього не можна мовчати! Ми маємо вчитися відкрито говорити про це, не бути байдужими до проблем інших, адже побороти насильство, змінити світ на краще можна лише завдяки спільним зусиллям!

\section{Список літератури:}

1. Офіційний сайт Ради Свропи 2020. URL: https://www.coe.int/uk/web/compass/gender

2. Громадське Телебачення. URL: https://hromadske.ua/posts/u-likarni-pislya-sprobi-samogubstva-pomer-15richnij-hlopec-iz-simyi-rodikovih-chiyi-batki-pomerli-vid-covid-19

3. Новини ООН (2020). Глава ООН закликає до єдності щодо мобілізації усіх сил для подолання пандемії коронавірусу. URL: https://news.un.org/en/story/2020/04/1061012 (дата звернення: 14.05.2021).

4. Аніщук Н.В. Правове становище українських жінок в історичному минулому : авторедр. дис. ... канд. юрид. наук : спец. 12.00.01 «Теорія та історія держави і права; історія політичних і правових учень»; Одеська. нац. юрид. академ. Одеса, 2008. С. 155-158.

5. Кісь О.Р. Жінка в традиційній українській культурі: друга половина XIX - початок XX ст. Львів, 2008.217 с.

6. Кісь О.Р. Моделі конструювання гендерної ідентичності жінки в сучасній Україні. Незалежний культурологічний часопис. 2003. URL: http://www.ji.lviv.ua/n27texts/kis.htm

7. Джилліген Дж. Запобігання насильству / пер. з англ. В.В. Штенгелов. Київ : Сфера, 2004. 168 с.

8. Кримінальний кодекс ФРГ від 19 червня 2019 року. URL: http://www.gesetze-im-internet.de/englisch_stgb/ englisch_stgb.html

9. Садонцева Л.К. Кримінальна відповідальність за домашне насильство в Україні та зарубіжному праві: порівняльний аналіз. Молодий вчений. 2019. № 4. С. 151.

10. Авдалян А.Я. Предупреждение преступлении против половой неприкосновенности несовершеннолетних: уголовно-правовой и криминологический аспекты (компаративистское исследование) : дис. ... канд. юрид. наук : 12.00.08 / Елецкий гос. ун-т им. И. А. Бунина. Елец, 2015. 211 с.

11. Аніщук Н.В. Правові засоби викорінення гендерного насильства в Україні: історико-теоретичний аналіз : автореф. дис. ... канд. юрид. наук : спец. 12.00.01 «Теорія та історія держави і права; історія політичних і правових учень»; Одеська. нац. юрид. академ. Одеса, 2008. С. 16.

12. Харитонова О.В. Домашне насильство та доступ жінок до правосуддя: правові бар'ери. Bicник Aсоиіацї кримінального права Украӥни. 2020. № 1. С. 43-45, 51-52.

13. Харитонова О.В. Ключові засади гендерної політики в кримінальному праві України та основні напрями реформ щодо протидії насильству стосовно жінок та домашньому насильству : Науково-практичний посібник. Харків : ТОВ Видавництво «Права людини», 2018. 344 с.

14. Засідання ВРУ. 34, 17.11.2016. URL: https://www.rada.gov.ua/meeting/stenogr/show/6366.html

15. Справа «ЛЕВЧУК ПРОТИ УКРАЇНИ», Свропейський суд 3 прав людини. URL: https://rm.coe.int/case-oflevchuk-v-ukraine-in-ukrainian-upd/16809fdc12 
16. Харитонова О.В. Суд і гендер: ЄСПЛ виніс перше рішення проти України щодо домашнього насильства. URL: 50vidsotkiv.org.ua.2020

17. Громадський простір. Wave Report 2015: як у Європі допомагають жінкам, що зазнали насильства. URL: https://www.prostir.ua/?focus=wave-report-2015-zhinky-evropy-proty-nasylstva

18. Журнал «WAVE Report» Жінки Проти Насилля В Європі 2015. URL: http://fileserver.wave-network.org/ researchreports/WAVE_Report_2015.pdf

19. Світовий Економічний Форум. Освіта у стосунках може допомогти зменшити домашне насильство. URL: https://www.weforum.org/agenda/2018/08/healthy-relationships-education-offers-a-real-chance-to-reducedomestic-violence

\section{References:}

1. Council of Europe 2020. URL: https://www.coe.int/uk/web/compass/gender

2. Hromads'ke Telebachennya. URL: https://hromadske.ua/posts/u-likarni-pislya-sprobi-samogubstva-pomer-15richnij-hlopec-iz-simyi-rodikovih-chiyi-batki-pomerli-vid-covid-19

3. United Nation News (2020) Hlava OON zaklykaye do yednosti shchodo mobilizatsiyi usikh syl dlya podolannya pandemiyi korona virusu [The head of the UN calls for unity in mobilizing all forces to overcome the coronary virus pandemic]. URL: https://news.un.org/en/story/2020/04/1061012 (accessed 14 May 2021).

4. Anishchuk N. (2008) Pravove stanovyshche ukrayins'kykh zhinok v istorychnomu mynulomu [Legal status of Ukrainian women in the historical past].

5. Kis O. (2008) Zhinka v tradytsiyniy ukrayins'kiy kul'turi: XIX-XX century [Woman in traditional Ukrainian culture: the second half of the XIX - early XX century].

6. Kis`O. (2003) Modeli konstruyuvannya gendernoyi identychnosti zhinky v suchasniy Ukrayini [Models of constructing a woman's gender identity in modern Ukraine]. Nezalezhnyy kul'turolohichnyy chasopys. URL: http://www.ji.lviv.ua/n27texts/kis.htm

7. Gilligan J. (2004) Zapobihannya nasyl'stvu / per. z anhl. V.V. Shtenhelov [Prevention of violence / trans. from English V.V. Shtengelov].

8. Kryminal'nyy kodeks FRH vid 19 chervnya 2019 roku [Criminal Code of Germany of June 19, 2019]. URL: http://www.gesetze-im-internet.de/englisch_stgb/englisch_stgb.html

9. Sadontseva L. (2019) Kryminal'na vidpovidal'nist' za domashnye nasyl'stvo v Ukrayini ta zarubizhnomu pravi: porivnyal'nyy analiz [Criminal liability for domestic violence in Ukraine and foreign law: a comparative analysis].

10. Avdalyan A. (2015) Preduprezhdeniye prestuplenii protiv polovoy neprikosnovennosti nesovershennoletnikh: ugolovno-pravovoy i kriminologicheskiy aspekty (komparativistskoye issledovaniye) [Prevention of crime against sexual inviolability of minors: criminal law and criminological aspects (comparative study)].

11. Anishchuk N. (2008) Pravovi zasoby vykorinennya hendernoho nasyl'stva v Ukrayini: istoryko-teoretychnyy analiz [The Right to Recognize Gender Violence in Ukraine: A Historical and Theoretical Analysis].

12. Kharitonova O. (2020) Domashnye nasyl'stvo ta dostup zhinok do pravosuddya: pravovi bar'yery [Domestic violence and women's access to justice: legal barriers]. Bulletin of the Association of Criminal Law of Ukraine, vol. 1 , pp. $43-45,51-52$.

13. Kharitonova O. (2018) Klyuchovi zasady hendernoyi polityky v kryminal'nomu pravi Ukrayiny ta osnovni napryamy reform shchodo protydiyi nasyl'stvu stosovno zhinok ta domashn'omu nasyl'stvu [Key principles of gender policy in the criminal law of Ukraine and the main directions of reforms to combat violence against women and domestic violence]. Scientific and practical manual. Kharkiv: Human Rights Publishing House LLC.

14. Zasidannya VRU № 34 vid 17.11.2016 [Meeting of the Verkhovna Rada]. URL: https://www.rada.gov.ua/meeting/ stenogr/show/6366.html

15. Sprava «LEVCHUK PROTY UKRAYINY», Yevropeys'kyy sud z prav lyudyny [LEVCHUK v. UKRAINE, European Court of Human Rights]. URL: https://rm.coe.int/case-of-levchuk-v-ukraine-in-ukrainian-upd/16809fdc12

16. Kharitonova O. (2020) Sud i hender: YESPL vynis pershe rishennya proty Ukrayiny shchodo domashn'oho nasyl'stva [Court and Gender: The ECHR issued the first decision against Ukraine on domestic violence]. URL: 50vidsotkiv.org.ua.2020

17. Hromads'kyy prostir (2015) Yak u Yevropi dopomahayut' zhinkam, shcho zaznaly nasyl'stva [How women in violence are helped in Europe]. URL: https://www.prostir.ua/?focus=wave-report-2015-zhinky-evropy-proty-nasylstva

18. WAVE WOMEN AGAINTS VIOLENCE EUROPE 2015. URL: http://fileserver.wave-network.org/researchreports/ WAVE_Report_2015.pdf

19. World Economic Forum. Relationship education could help reduce domestic violence. URL: https://www.weforum.org/ agenda/2018/08/healthy-relationships-education-offers-a-real-chance-to-reduce-domestic-violence 